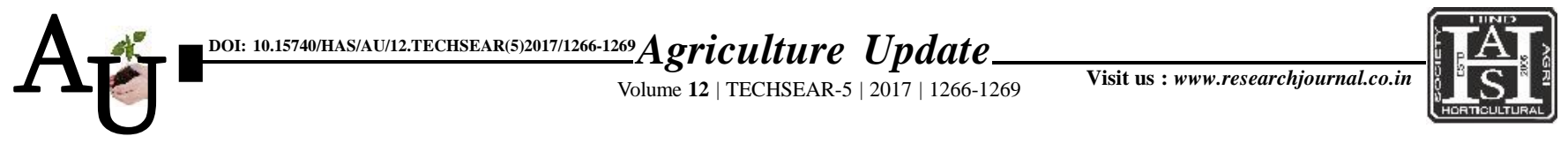

\title{
Research Article: Effect of soil test based nutrient management approaches on growth and yield of dry direct seeded rice (Dry DSR)
}

RAGHAVENDRA, K. NARAYANA RAO, S.P. WANI, M.V. RAVI, H. VEERESH, A.S. CHANNABASAVANNA AND MAHADEVA SWAMY

Article Chronicle : Received :

15.07.2017;

Accepted :

30.07.2017

KEY WoRds :

Dry direct seeded rice, Targeted yield approach, Soil test, Growth, Yield
SUMMARY : An experiment was conducted during Kharif and Rabi seasons of 2015-16 and 2016-17in the farmer field of Vijayanagar camp, Tq/Dist: Raichur, to identify the suitable nutrient management approaches for enhancing production potentials of Dry DSR-mustard cropping system. The experiment consisted of ten treatments with application of different category of nutrients as per soil test based nutrient management approaches including control and farmers fertilizers practice. Significantly higher grain (54.73 $\left.\mathrm{q} \mathrm{ha}^{-1}\right)$ and straw (68.38 $\left.\mathrm{qa}^{-1}\right)$ yield of rice was recorded in SSNM approach targeted yield of $55 \mathrm{q} \mathrm{ha}^{-1}\left(\mathrm{~T}_{8}\right)$ and the increase was to anextent of 7.9 and 16.7 per cent, respectively when compared to Farmers' Fertilizer Practice (FFP). The increase in grain and straw yield of rice in $\mathrm{T}_{8}$ could be due to the maximum number of panicles per $\mathrm{m}^{-2}(438.1)$, Length of panicle $(19.8 \mathrm{~cm})$, Number of grains per panicle (143.9), Test weight (13.98 g), lower sterility percentage (6.8), higher plant height $(72.8 \mathrm{~cm})$, higher dry matter production $\left(62.25 \mathrm{~g} \mathrm{plant}^{-1}\right)$, higher number of tillers $\mathrm{m}^{-2}(678.0)$ and maximum leaf area $\left(1418 \mathrm{~cm}^{2}\right.$ plant $\left.{ }^{-1}\right)$.

How to cite this article : Raghavendra, Rao, K. Narayana, Wani, S.P., Ravi, M.V., Veeresh, H., Channabasavanna, A.S. and Swamy, Mahadeva (2017). Effect of soil test based nutrient management approaches on growth and yield of dry direct seeded rice (Dry DSR). Agric. Update, 12(TECHSEAR-5) : 1266-1269; DOI: 10.15740/HAS/ AU/12.TECHSEAR(5)2017/1266-1269.
Author for correspondence :

\section{RAGHAVENDRA}

Department of Soil

Science and Agricultural

Chemistry, University of

Agricultural Sciences,

RAICHUR (KARNATAKA)

INDIA

See end of the article for

authors' affiliations 